\title{
Effects of Oestrogenic Silage on Some Clinical and Endocrinological Parameters in Ovariectomized Heifers
}

\author{
By A.I. Nwannenna ${ }^{1 *}, A$. Madej $^{2}$, T.J-O. Lundh ${ }^{3}$ and G. Fredriksson ${ }^{1 \dagger}$ \\ ${ }^{1}$ Departments of Obstetrics and Gynaecology, ${ }^{2}$ Physiology, and ${ }^{3}$ Animal Nutrition and Management, Swedish \\ University of Agricultural Sciences, Uppsala, Sweden.
}

\begin{abstract}
Nwannenna A.I., A. Madej, T.J-O. Lundh and G. Fredriksson: Effects of oestrogenic silage on some clinical and endocrinological parameters in ovariectomized heifers. Acta vet scand. 1994, 35, 173-183. - The influence of phytoestrogens was studied in 3 ovariectomized Swedish Friesian heifers fed $20 \mathrm{~kg}$ of $100 \%$ red clover silage per heifer/day for 14 days. Behaviour, reproductive organs and pitutary response to exogenous gonadotropın-releasıng hormone $(\mathrm{GnRH})$ injectıons were monitored. Clinical effects like oedema and mucous discharge in the vulva, presence of milky fluid in the mammae and increases in teat size and the cross-sectional distance of the uterus were observed in heifers fed red clover silage. Fluid accumulation in the uterus, visualized by means of ultrasonography, had still not disappeared 30 days after the red clover silage had been completely withdrawn. Red clover silage appeared to reduce the magnitude and duration of the pituitary response to GnRH injections.
\end{abstract}

reproductive organs; LH; GnRH; phytoestrogens; red clover.

\section{Introduction}

Phytoestrogens are oestrogen-mimics produced in high amounts by leguminous plants such as clover, lucerne and soyabeans. Red clover is quantitatively the most important source of phytoestrogens in Sweden. The concentration of phytoestrogens in red clover is normally about $0.5-2.5 \%$ of dry matter (Pettersson et al. 1984). The amount of phytoestrogens in red clover varies very little between different varieties of red clover. A greater variation depends on other factors such as climate (Pettersson et al. 1984), phosphorus sup-

$\dagger$ Deceased.

* Permanent address: Ahmadu Bello University, Faculty of Veterinary Medicine, Department of Surgery and Medicine, Zaria, Nigeria. ply and light (Cocks et al. 1980). The concentration of phytoestrogens in animal feed also depends on the time of harvest and methods for preservation. Field cured hay reduces the oestrogenic activity by about $70 \%$ (Nilsson 1960). On the other hand, ensiling not only preserves the oestrogenic activity (Kallela 1975, Kallela 1980) but even increases it (Jorgensen \& Freymiller 1974, Kallela 1980). Oestrogenic compounds from plants are classified as isoflavones and coumestans and their structure are similar to non-steroidal synthetic oestrogens (Price \& Fenwick 1985). It has long been known that phytoestrogens cause both temporary and permanent infertility in sheep (Bennetts et al. 1946, Adams 1989). Reproductive disturbances have also been reported in cattle in some countries (Thain 1966, Kallela 
1968, Kallela et al. 1984, Pettersson et al. 1984, Shemesh \& Shore 1987). However, it has been suggested that the ingestion of phytoestrogens by cattle might result in temporary but not in permanent infertility (Adams 1989). Although the reason(s) for this difference in response has been the subject of controversy (Braden et al. 1971, Lundh et al. 1990), it seems probable that dissimilarities in phytoestrogen metabolism are involved. The manner in which phytoestrogens disturb the oestrogen and gonadotropin balance in animals has mainly been studied in sheep (Findlay et al. 1973, Hearnshaw et al. 1977, Rodgers et al. 1980, Bindon et al. 1982, Adams \& Martin 1983, Montgomery et al. 1985). To our knowledge, no hormonal studies have been carried out in cattle exposed to phytoestrogens. The aim of this experiment was therefore to monitor changes in mammary glands and reproductive organs and the LH response to administration of exogenous GnRH in ovariectomized heifers fed red clover silage.

\section{Materials and Methods}

\section{Animals and feeding}

Three clinically healthy, normally cycling heifers of the Swedish Friesian Breed, about 2 years old and weighing $550-600 \mathrm{~kg}$, were used. In November, the heifers were bilaterally ovariectomized through a flank incision as was described by Åström (1972) but using other premedication. Briefly, sedation was performed with Rompun ${ }^{\circledR}$ vet. (Bayer) (0.1 $\mathrm{mg} / \mathrm{kg}$ of xylazine i.m.) including local nerve block with Xylocaine ${ }^{\circledR}$ adrenaline (Astra) (10 $\mathrm{mg} / \mathrm{ml}$ of lidocaine and $5 \mu \mathrm{g} / \mathrm{ml}$ of adrenaline). The mesovarium was slowly crushed with the ecraseur and the ovary retained in the hand. Then, the peritoneum, musculature and skin were sutured. The general condition of the animals was scarcely affected by the operation.
The heifers were kept indoors and normally received about $15 \mathrm{~kg}$ of nonestrogenic hay (mainly Timothy grass) and $750 \mathrm{~g}$ concentrates $(39 \%$ barley, $39 \%$ oats, $11 \%$ soya, $7 \%$ rapeseed and $4 \%$ other additions) per heifer per day except during experimental feeding periods. However, they had free access to mineral licks and good drinking water at all times. To provide phytoestrogens the animals were fed red clover silage during the experimental period. The high performance liquid chromatographic method described by Pettersson \& Kiessling (1984) was used to determine the oestrogen contents of homogenous samples taken from hay, concentrates, and red clover silage fed to the heifers in this experiment. The hay and concentrates contained no oestrogens. The red clover silage contained a total of $1.74 \mathrm{~g}$ oestrogens (1.01 $\mathrm{g}$ formononetin, $0.03 \mathrm{~g}$ daidzein, $0.61 \mathrm{~g}$ biochanin- $\mathrm{A}$, and $0.08 \mathrm{~g}$ genistein) per $\mathrm{kg}$ wet weight. The fodder for the heifers was gradually changed by decreasing the proportions of hay and increasing the proportions $(20 \%, 30 \%, 50 \%, 50 \%$, $75 \%, 75 \%$ ) of red clover silage over a period of 6 days to allow the rumen microbial populations in these heifers to adapt. From day 7 to day 20 the fodder consisted entirely of red clover silage. At 0730 and $1430 \mathrm{~h}$ each heifer received a maximum of $10 \mathrm{~kg}$ silage per feeding, corresponding to about $35 \mathrm{~g}$ phytoestrogens per day. Beginning on day 21, silage was gradually replaced with hay over another period of 6 days.

\section{Blood sampling}

Two months after ovariectomy, intravenous jugular catheters were introduced into the heifers under local anaesthesia. Prior to feeding with red clover silage and on the last day of maximum red clover feeding, $10 \mathrm{ml}$ blood samples were collected into heparinized tubes from each heifer at 10 min intervals for $6 \mathrm{~h}$ 
(0830 - 1430 h). A single intramuscular injection of $100 \mu \mathrm{g}$ synthetic GnRH (gonadorelin; Nialutin ${ }^{\circledR}$, Boeringer Ingelherm Agrovet/BIvet) was given to each heifer $60 \mathrm{~min}$ after the start of sampling. All blood samples were centrifuged immediately after collection. Plasma samples were stored at $-20^{\circ} \mathrm{C}$ until analysis.

\section{Clinical examination}

The condition of the reproductive organs and behaviour of all heifers were clinically evaluated prior to the beginning of the feeding experiment. Subsequently, these examinations were repeated twice a week until slaughter. Observations on udder growth, its consistency and signs of milk secretion were done accordingly. Teat length was measured according to the method of Gardnar \& Adams (1986) except that permanent markers were used instead of tattoos. To measure teat circumference, we used thin, long nylon strings, calibrated $(\mathrm{mm})$ in the middle along a distance of $10 \mathrm{~cm}$. Each $\mathrm{cm}$ interval was given a different colour. The string was circled round the base of the teat and the circumference was recorded. Contact between teat and string was ascertained without pressure on teat or space between teat and string.

The colour of the vulva was recorded, and it was examined for signs of mucous discharge and oedema. Arbitrary scores were assigned to changes in each parameter, ranging from 1 (no change) to 5 (severe change). The sum of the scores for changes in the 3 parameters was recorded for each period of vulva examination.

Uterine response was assessed by rectal palpation and transrectal ultrasonography. The uteri were palpated and scanned 3 days before ovariectomy, 4 days before the feeding of red clover silage started and, thereafter, twice weekly. Palpation was used to check for the presence of tone. Uterine tone was scored from 1 (flabby or atonic) to 5 (contracted and firm).

Ultrasound examinations were performed using an Aloka SSD-210DX (Aloka Co. Ltd., Tokyo, Japan) portable real-time B-mode linear scanner with a $5 \mathrm{MHz}$ transducer inserted into the rectum. The uterus was located by rectal palpation and then scanned around the bifurcation. Screen images of the uterine horns were then frozen for cross-sectional distance measurements, examination of the uterine lumen and Polaroid ${ }^{\circledR}$ photography.

Heifers were slaughtered 30 days after the last red clover silage feeding. The uteri were then visually examined to check phytoestrogen effects.

Changes in teat length and uterine diameter were expressed in percent of individual pretreatment values.

\section{Hormone assay and analysis of $L H$ data}

Luteinizing hormone concentrations were measured in all blood samples using a heterologous radioimmunoassay validated for bovine plasma according to Forsberg et al. (1993). Assay sensitivity for $100 \mu \mathrm{l}$ plasma, calculated from the precision profiles, averaged $0.7 \mu \mathrm{g} / \mathrm{l}$. The intra-assay coefficients of variation were $<8 \%$ for concentrations exceeding $1 \mu \mathrm{g} / 1$. Inter-assay coefficients of variation were $<10.6 \%$ for concentrations of 3.2 , 6.6, and $11.7 \mu \mathrm{g} / 1$

LH values in $\mu \mathrm{g} / 1$ were plotted against collection time $(6 \mathrm{~h})$ for each heifer to visualize the magnitude and duration of response to $\mathrm{GnRH}$ injection in each case. Area under the curve (AUC), in $\mathrm{mm}^{2}$, for each profile was determined using an electronic integrator (Digiplan, Kontron Messgeräte, FRG). The area due to pituitary response was calculated by subtracting the area above basal levels that follow injection of GnRH from the total area. The basal LH level for GnRH treatment pro- 


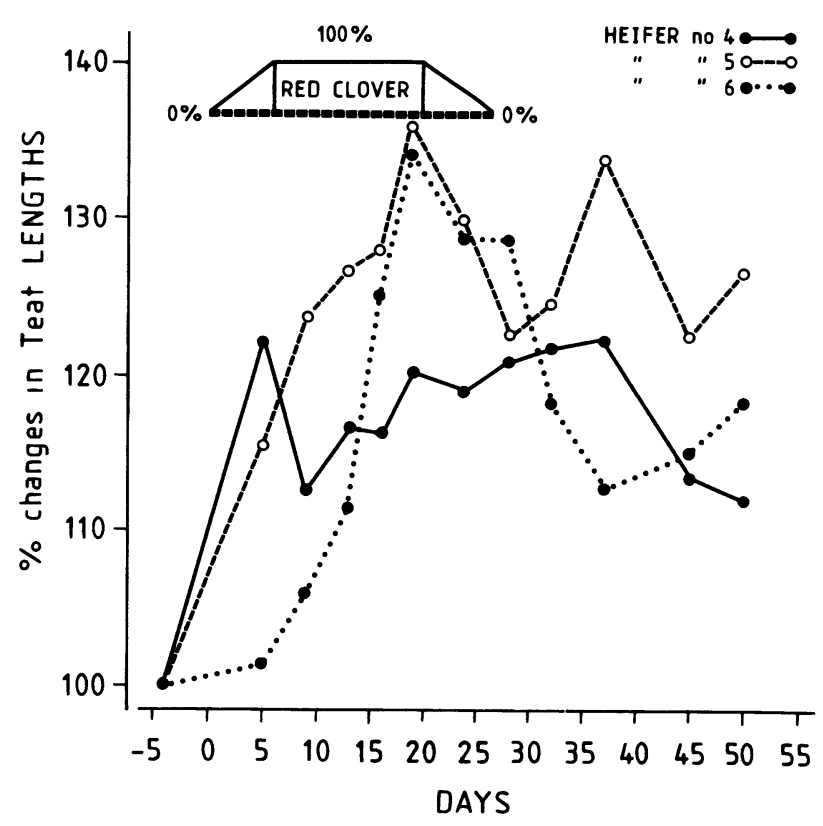

Figure 1. Percent change in teat length in relation to the initial values for individual ovariectomized heifers fed red clover silage. The timing of the introduction and withdrawal of silage is shown within the box entitled RED CLOVER.

files was calculated as the mean of all values before GnRH injection plus their 2 standard deviations. The duration of $\mathrm{LH}$ response to GnRH was calculated as the time interval between the point of GnRH injection and the point at which the response curve dropped back to basal levels. Peak time was defined as the time interval between injection of GnRH and the highest $\mathrm{LH}$ concentration within the response interval.

\section{Results}

\section{Clinical examination}

The percent change in average teat lengths, uterine diameters, and the scores for vulva as well as uterine tone, are presented for each heifer in Fig. 1-4.

Teat length increased by $22 \%$ within 5 days in heifer no. 4. In heifers nos. 5 and 6 teat length peaked at about $35 \%$ on day 18 (Fig. 1). Changes in teat circumference were negligible. Milky fluid secretion from mammae was observed in heifers nos. 4 and 5.

In all 3 heifers the vulva responded to red clover by changing colour (from pale to pink), swelling, and discharging mucus. The sum of the response scores was almost identical in all heifers. The responses became apparent 13 (no. 4) and 16 (nos. 5 and 6) days after introducing red clover silage and continued to increase until a peak was reached 6 days after complete withdrawal (Fig. 2). Just before slaughter vulva scores were still at level 3 in 2 heifers, whereas in the third heifer it had dropped to zero.

Prior to ovariectomy palpation indicated that the uteri had a very strong tonus (score $=5$ ) in heifers 4 and 5 and moderate tonus (score $=3$ ) in heifer no. 6. Corresponding ultrasonogra- 


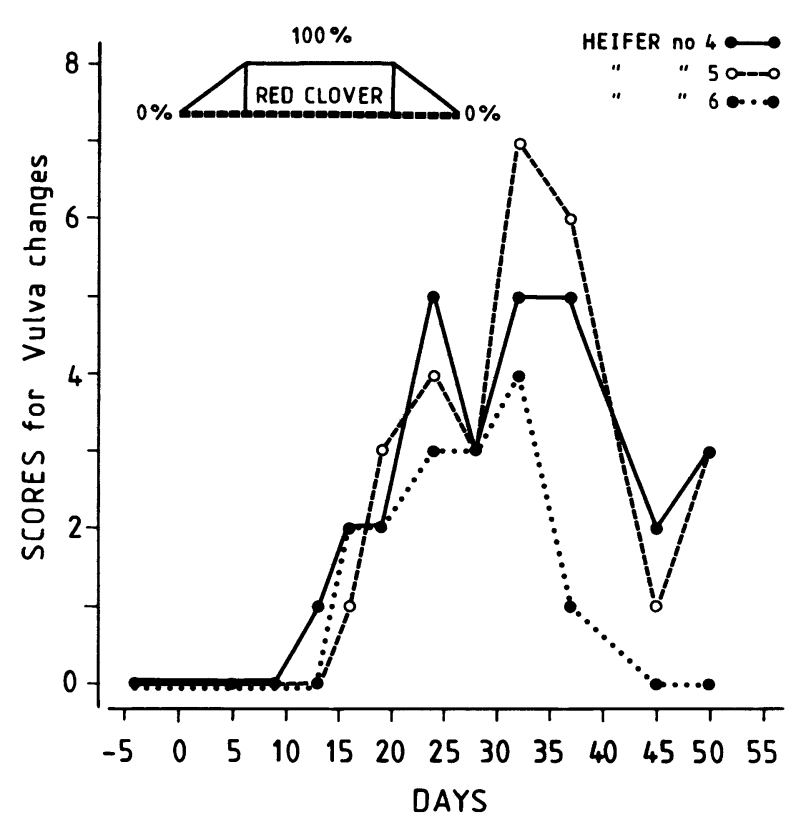

Figure 2. Vulva scores for individual ovariectomızed heifers fed red clover silage. The tımıng of the introduction and withdrawal of slage is shown within the box entitled RED CLOVER.

phy revealed clear echogenic endometrial folds with a nonechogenic, stellate lumen for heifers 4 and 5. A more clearly distinguishable myometrium and homogenous grey lumen without evidence of interstitial oedema was seen in heifer 6 . Heifers nos. 4 and 5 were confirmed to be in oestrus based on the presence of the characteristic oestrous discharge from the vulva a few hours before ovariectomy.

Two months after ovariectomy, and prior to the feeding of red clover silage, all uteri were hardly palpable and lacked tone (Fig. 3). The ultrasonographs showed cornua that were very much reduced in size and lacked demarcation between myometrium and endometrium. In response to the ingestion of red clover silage, uteri gradually acquired tonus and became palpable. Uterine tone reached a maximum between days 19 and 24 and declined thereafter (Fig. 3). Ultrasonography re- vealed cross sections of uterine horns that were increased in size in a fluctuating manner, sometimes with mixed patches of echogenic and nonechogenic areas in the lumen. The percent increase in the average diameter of the uterine horns reached a maximum on day 13 in heifer $4(30 \%)$, day 20 in heifer $5(50 \%)$, and day 28 in heifer 6 (40\%) (Fig. 4).

On 1 of the red clover silage exposure days, 1 heifer seemed restless and mounted other heifers.

After slaughtering the heifers, gross examination of the reproductive genitalia revealed accumulations of greyish watery fluid in the anterior vagina $(15-23 \mathrm{ml})$ of all 3 animals and in the uterus $(8$ and $15 \mathrm{ml})$ of 2 . The anterior third of the left ovarian tube with a diameter of $4 \mathrm{~mm}$ in heifer no. 4 was blocked and contained fluid. Cervices were relaxed and the external os felt patent on palpation. 


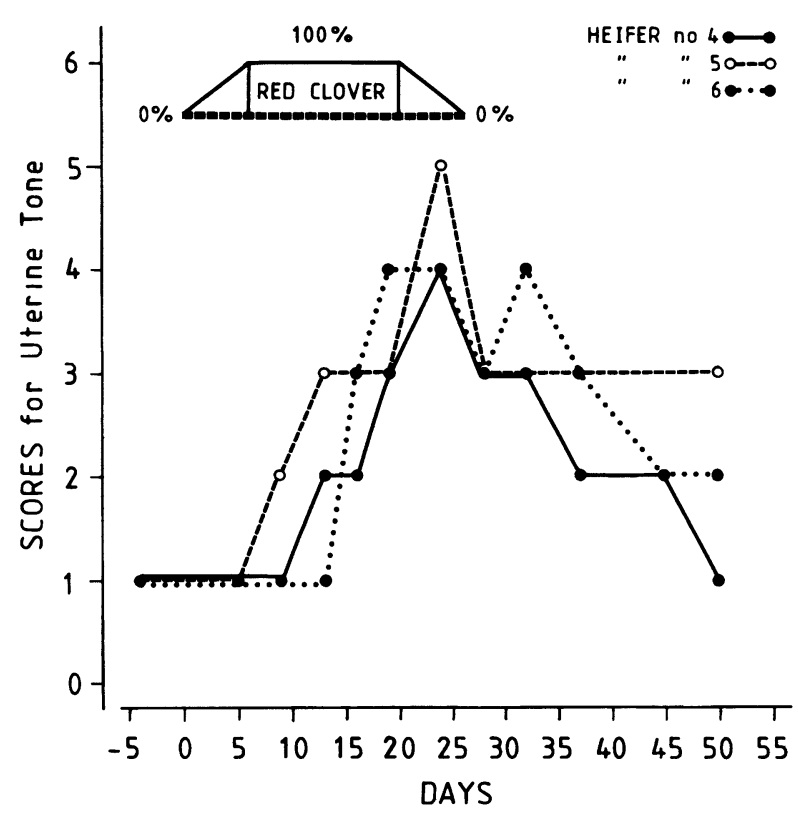

Figure 3. Uterıne tone scores for individual ovariectomized heifers fed red clover slage. The tımıng of the introduction and withdrawal of silage is shown within the box entitled RED CLOVER.

\section{$L H$ values}

Plasma LH concentrations increased greatly within 5-10 min of injecting GnRH, in every case where grass hay or red clover silage was being ingested (Fig. 5). The duration of this response was longer during hay feeding than during exposure to red clover silage in 2 heifers (293 min vs $226 \mathrm{~min}$ in heifer 4 and $264 \mathrm{~min}$ vs $247 \mathrm{~min}$ in heifer 5). The time that elapsed before this response reached maximum was also 10 min longer during hay feeding in both these heifers. Additionally, it appeared that both the total and response AUC were greater during the control period in the same heifers (i.e., total AUC - $4823 \mathrm{~mm}^{2}$ vs 4338 $\mathrm{mm}^{2}$ in heifer 4 and $4377 \mathrm{~mm}^{2}$ vs $2894 \mathrm{~mm}^{2}$ in heifer 5; response AUC - $3286 \mathrm{~mm}^{2}$ vs 2486 $\mathrm{mm}^{2}$ in heifer 4 and $3017 \mathrm{~mm}^{2}$ vs $2099 \mathrm{~mm}^{2}$ in heifer 5). Heifer no. 6 responded oppositely.

\section{Discussion}

This paper reports on the effects that oestrogenic red clover has on the mammary glands and the reproductive organs of ovariectomized heifers. Teat length reached a maximum after about 12 days of maximum exposure to red clover and declined about 2-3 weeks following withdrawal. Similar observations were made by us (Nwannenna 1993) in a similar experiment with ovariectomized ewes and by Adams (1977) in wethers grazing on oestrogenic subterranean clover over a period of 10 days. The change observed in the teat circumference of ewes was not seen in these heifers.

The increase in vulva scores during red clover feeding is in agreement with clinical field observations made by Adler \& Trainin (1960) who reported swollen vulvae with hyper- 


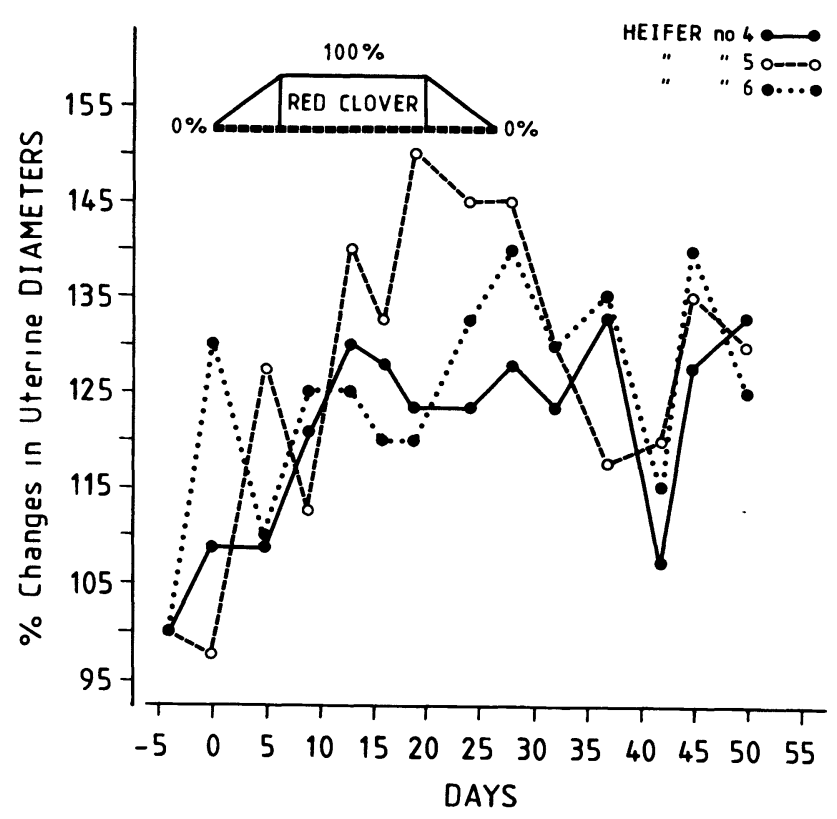

Figure 4. Percent change in the uterıne diameter, in relatıon to the initıal values, for indıvidual ovariectomized heifers fed red clover slage. The timing of the introduction and withdrawal of silage is shown within the box entitled RED CLOVER.

aemic, glistening mucous membrane in alfalfa-fed heifers in various stages of their oestrous cycle.

The uterine response to ovariectomy included a reduction in the cross-sectional distance of the uterine horns by an average of about $20 \%$ and decrease in the tone score from 3-5 to 1. These responses were gradually reversed when heifers were exposed to red clover silage. Pierson and Ginther (1987) found that the ultrasonographic appearance and mean distances from the dorsal surface of the uterine body to the ventral surface were influenced by the stage of the oestrous cycle. The mean distances were highest around ovulation. Similarly, clinical examination of anestrous cows will show a flabby and atonic uterus which reverses and becomes erect and turgid during oestrus (Settergren 1980, Ro- berts 1986). Endometrial folds and the myometrium were visible in the ultrasonographic pictures taken 3 days before oestrus and ovariectomy in 2 of our heifers. Fissore et al. (1986) reported that it is usually possible to distinguish the endometrial folds and myometrium as well as small accumulations of fluid in the uterine lumen with ultrasonography in oestrous cows. They suggested these findings to be due to the high oestrogen concentrations typical of the periovulatory period. In our study, this endometrial fold architecture seen before ovariectomy became distorted, with disorganized locations of fluid pockets, when heifers were exposed to phytoestrogens. We presumed that this distortion represented some kind of pathology which could be analogous to the doughy and pendulous uteri found in cows grazing on oestrogenic subterranean 


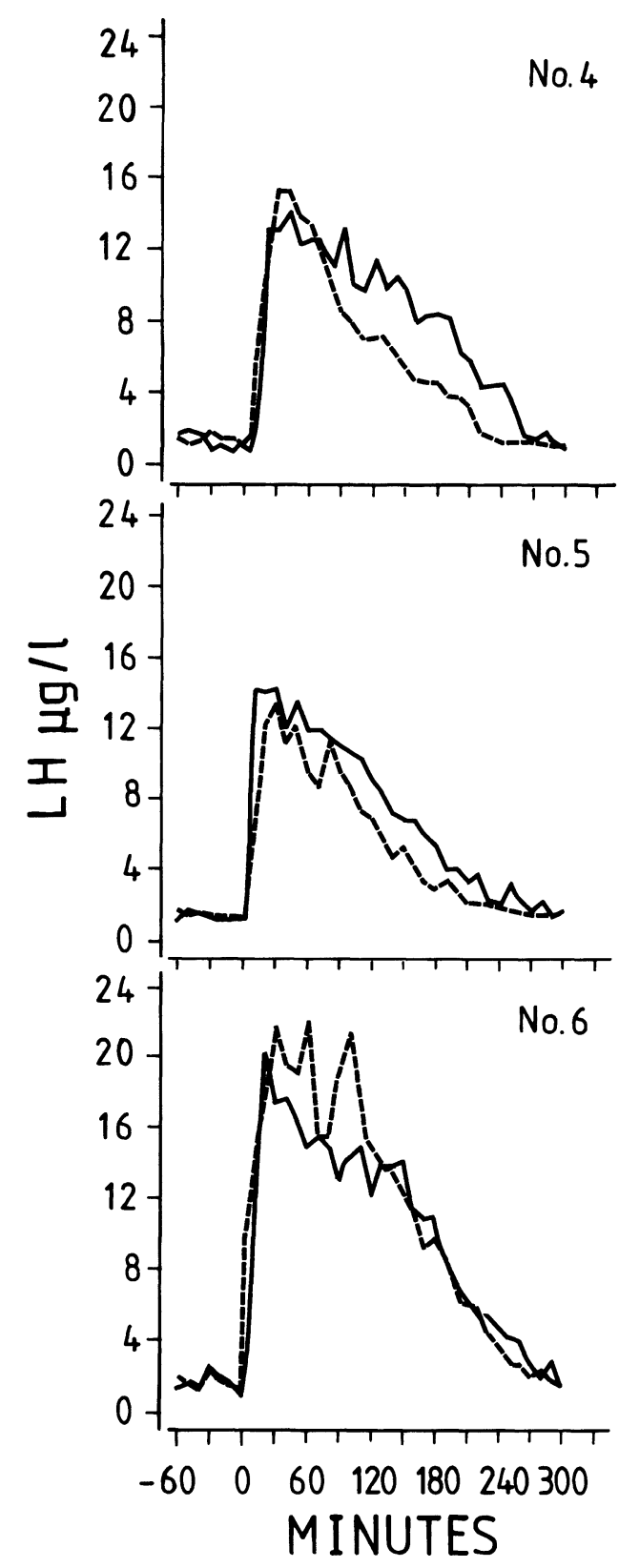

Figure 5. Plasma LH concentrations in individual ovariectomized heifers injected with GnRH before (—) and during (-------) exposure to phytoestrogens. clover by Thain (1966). Further more, this is probably a primary stage (in these heifers) of the cystic endometrial condition reported by Bennetts et al. (1946) in ewes grazing subterranean clover pasture.

The mounting behaviour seen in one of our heifers is in agreement with previous reports of mounting in heifers on red clover pasture (Kallela 1968) and heat periods in cattle grazing on alfalfa (Adler \& Trainin 1960) as well as the pattern of sexual behaviour in ovariectomized heifers treated with oestradiol (Katz et al. 1980).

The synthetic decapeptide known as GnRH acts on the anterior pituitary to initiate a release of LH in intact (Schams et al. 1974, Jensen et al. 1983) or ovariectomized heifers (Hausler \& Malven 1976). Our findings of a lower total as well as a reduced response $\mathrm{LH}$ area under the curve after GnRH injection in 2 heifers fed red clover silage compared to when they were fed hay are in agreement with the report by Hinshelwood et al. (1986). These authors found that the release of $\mathrm{LH}$ in response to GnRH in ovariectomized cows differed, depending on when GnRH was administered in relation to oestradiol-17 $\beta$ pretreatment. The area under the LH curve was smaller for cows receiving the GnRH injection $2.5 \mathrm{~h}$ after oestradiol-17 $\beta$ than for those receiving the placebo. No such difference was found when $\mathrm{GnRH}$ was administered $5 \mathrm{~h}$ after oestradiol-17 $\beta$ injection. In ovariectomized cows the concentration of $\mathrm{LH}$ can be inhibited by oestradiol-17 $\beta$ for up to $12 \mathrm{~h}$ (Rhodes et al. 1980, Madej et al. 1981, Kesner et al. 1981). These authors concluded that the first phase of this inhibitory period, i.e. 2-4 $\mathrm{h}$ after oestradiol administration may occur owing to a relatively low responsiveness to $\mathrm{GnRH}$. Plasma concentrations of formononetin and its metabolite daidzein in cows fed red clover silage increase significantly within $1 \mathrm{~h}$ after 
feeding (Lundh et al. 1990). Furthermore, Markiewicz et al. (1993) found that daidzein had oestrogenic activity as a result of its interaction with oestrogen receptors. The data on low $\mathrm{LH}$ response to GnRH during phytoestrogen exposure, found here, require corroboration in future experiments using several more animals.

In conclusion, a daily intake of $35 \mathrm{~g}$ phytoestrogens from Swedish red clover silage induce changes in the behaviour, reproductive organs and may affect the pituitary response to $\mathrm{GnRH}$ in ovariectomized heifers.

\section{Acknowledgement}

This study was supported by a grant from the Swedish Councl for Forestry and Agricultural Research. Financial support for A.I. Nwannenna from the Swedish International Programme on Animal Reproduction is gratefully acknowledged. Hormone analyses were carried out at the Department of Clinical Chemıstry. We are also grateful to Ms Catharına Falkenberg for efficient assistance in all aspects of this work and to Ms Mari-Anne Carlsson for skillful technical help. The authors wish to thank Professor Göran Åstrom for fruitful dıscussıon and critıcısm. Ahmadu Ballo University, Nigeria is acknowledged for grantıng A.I.N. study leave.

\section{References}

Adams NR: Morphological changes in the organs of ewes grazing oestrogenic subterranean clover. Res. vet. Sci., 1977, 22, 216-221.

Adams NR: Phytoestrogens. Toxicants of plant or1gin Vol. IV. Phenolics pp 23-51. Ed. PR Cheeke. Boca Raton, 1989.

Adams NR, Martin GB: Effects of oestradiol on plasma concentration of luteinizing hormone in ovariectomized ewes with clover disease. Aust. J. biol. Sc1., 1983, 36, 295-303.

Adler JH, Trainin D. A hyperoestorgenic syndrome in cattle. Refuah. Vet., 1960, 17, 108-115.

Bennetts HW, Underwood EJ, Shier FL: A breeding problem of sheep in the South-West Division of Western Australia. J. Dept. Agric. West. Aust., 1946, 23, 1-12.

Bindon BM, Adams NR, Piper LR: Effects of oestrogenic pasture on lutemizing hormone levels and the response to GnRH in female lambs. Anim. Reprod. Sci., 1982, 5, 7-13.

Braden AWH, Thain RI, Shutt DA. Comparison of plasma phyto-oestrogen levels in sheep and cattle after feeding on fresh clover. Aust. J. Agric. Res., 1971, 22, 663-670.

Cocks PS, Mathison MJ, Crawford RH: From wild plants to pasture cultivars: Annual medics and subterranean clover in Southern Australia. In: Eds. Summerfield RJ. and Bunting AH. Advances in Legume Science, Richmond, 1980, pp 569-596.

Findlay JK, Buckmaster JM, Chamley WA, Cumming IA, Hearnshaw H, Goding JR: Release of luteinızing hormone by oestradiol-17 $\beta$ and a gonadotrophin-releasing hormone in ewes with clover disease. Neuroendocrinology, 1973, 11, 57-66.

Fissore RA, Edmondson AJ, Pashen RL, Bondurant $R H^{\cdot}$ The use of ultrasonography for the study of the bovine reproductive tract II. Non-pregnant, pregnant and pathological conditions of the uterus. Anim. Reprod. Sc1., 1986, 12, 167-177.

Forsberg M, Tagle R, Madej A, Molina JR, Carlsson $M-A$ : Radioimmunoassay of bovine, ovine and porcine luteınıing hormone with a monoclonal antıbody and a human tracer. Acta vet. scand., 1993, 34, 255-262.

Gardnar JJ, Adams NR: The effect of zeranol and testosterone on Merino wethers exposed to highly oestrogenic subterranean clover pasture. Aust. vet. J., 1986, 63, 188-190.

Hausler CL, Malven PV: Interaction of progesterone, GnRH and estradiol in the control of LH in castrate heifers. J. Anım. Sc1., 1976, 42, 1239-1243.

Hearnshaw H, Cumming IA, Goding JR: Effect of ingestion of oestrogenic clover on lutemizing hormone release in the ovariectomized ewe. Aust. J. Biol. Sci., 1977, 30, 217-223.

Hinshelwood MM, Dierschke DJ, Hauser ER: The negative feedback effect of estradiol-17 $\beta$ on secretion of luteinizing hormone in beef cows. Theriogenology, 1986, 26, 323-331.

Jensen M, Myrup Pedersen K, Agger JF, MadeJ A: Plasma luteinızing hormone response to increasing doses of synthetic gonadotrophin-releasing hormone in heifers. Acta. vet. scand., 1983, 24, 211-224.

Jorgensen NA, Freymiller DD: Estrogenic activity of fermented alfalfa. J. Dairy Sci, 1974, 55, 80-82. 
Kallela $K$ : The oestrogenic effect of red clover pasture on the ovariectomized heifer. Nord. Vet.Med., 1968, 20, 185-192.

Kallela $K$ : The effect of storage on estrogenic effect of red clover silage. Nord. Vet.-Med. 1975, 27, 562-569.

Kallela $K$ The estrogenic effect of silage fodder. Nord. Vet.- Med, 1980, 32, 180-186.

Kallela K, Heınonen K, Salonıemı H. Plant oestrogens; the cause of decreased fertility in cows. A case report. Nord. Vet.-Med., 1984, 36, 124129.

Katz LS, Oltenacu, EAB, Foote RH. The behavioral response in ovariectomized cattle to either estradiol, testosterone, androstenedione, or dihydrotestosterone. Horm. Behav., 1980, 14, 224235.

Kesner JS, Convey EM, Anderson CR. Evidence that estradiol induces the preovulatory $\mathrm{LH}$ surge in cattle by increasing pituitary sensitivity to LHRH and then increasing LHRH release Endocrinology, 1981, 108, 1386-1391.

Lundh TJ-O, Pettersson HI, Martinsson KA. Comparative levels of free and conjugated plant estrogens in blood plasma of sheep and cattle fed estrogenic silage. J. Agric. Food Chem., 1990, 38, 1530-1534.

Madej A, Barcıkowskı B, Stupnıckı R, Kula E, Blnienda $Z$. Luteinizing hormone response to injection of synthetıc gonadotrophin releasıng hormone or infusion of oestradiol-17 beta in heifers. Anım. Reprod. Sc1., 1980, 3, 17-21.

Markıewıcz L, Garey J, Adlercreutz H, Gurpıd E· In vitro bioassay of non-steroidal phytoestrogens. Steroid Biochem. Molec. Biol., 1993, 45, 399405.

Montgomery GW, Martın GB, Le Bars J, Pelletıer J: Gonadotrophin release in ovariectomized ewes fed different amounts of coumestrol. J. Reprod. Fert., 1985, 73, 457- 463.

Nilsson A: The oestrogenic activity of hay and silage from some Swedish forage plants. Kungl. Lantbrukshogskolans Annaler, 1960, 26, 204206.

Nwannenna $A I \cdot$ Phytoestrogens in ruminant reproduction: Studies on the genitalia, mammae and luteinızıng hormone. MVSc thesis, Swedish University of Agricultural Sciences, Uppsala, 1993, pp. 1-29.

Pettersson H, Holmberg T, Kiessling K-H, Rutqvist $L$ : Vaxtostrogener i foder och reproduktıonsstorningar hos idisslare (Plant oestrogens in feed and reproductive disorders in ruminants). Svensk Veterinartidning, 1984, 36, 677-683.

Pettersson $H$, Klessling $K-H$ : Liquid chromatographic determination of the plant estrogens coumestrol and isoflavones in animal feed. J. Assoc. Off. Anal Chem., 1984, 67, 503-506.

Pierson RA, Ginther OJ Ultrasonographic appearance of the bovine uterus during the estrous cycle. J. Amer. vet. Med. Ass., 1987, 190, 995-1001.

Price KR, Fenwick GR: Naturally occurring oestrogens in foods - A Review. Food Additives and Contaminants, 1985, 2, 73-106

Rhodes III RC, Forrest PK, Randel RD. Reproductive studies of brahman cattle $V$. The effect of various dose levels of estradiol-17ßupon serum luteınızing hormone in ovariectomized brahman cows. Theriogenology, 1980, 13, 419-431

Roberts SJ: Examınations for pregnancy. Veterınary Obstetrics and Genital Diseases pp 14-37. Ed. SJ Roberts Woodstock Vermont, 1986.

Rodgers RJ, Clarke IJ, Findlay JK, Brown A, Cumming IA, Muller BD, Walker SK· Plasma LH and FSH in ewes that were either fertile or infertile after long-term grazing of oestrogenic pasture. Aust. J. Biol. Sc1., 1980, 33, 213-220.

Schams D, Hofer F, Schallenberger E, Hartl M, Karg $H$ : Pattern of luteinızing hormone (LH) and follicle stımulatıng hormone (FSH) in bovine blood plasma after injection of a synthetic gonadotrophin-releasıng hormone (GnRH). Therıogenology, 1974, 1, 137-151.

Settergren I: Physical examination of the bovine female reproductive system. Current Therapy in Therıogenology pp 159-164. Ed. DA Morrow. WB Saunders Co, Philadelphia, 1980.

Shemesh M, Shore LS . Non-steroldal oestrogens of dietary origin: Activity, distribution and mechanism of action. Isr. J. Vet. Med., 1987, 43, 192197.

Thain RI: Bovine infertılity possibly caused by subterranean clover. Aust. Vet. J., 1966, 42, 199-203.

Åstrom $G$ : On the influence of ovariectomy, diethylstilboestrol and progesterone on healthy and clinically infected bovine udders. Acta vet. scand., Suppl 39, 1-105.

\section{Sammanfattning}

Kliniska och endokrinologiska forandringar hos ovariectomerade kvigor som utfodrats med ostrogent ensilage.

Inverkan av vaxtostrogener studerades på 3 ovarie- 
ektomerade kvıgor, svensk låglandsboskap (SLB), som vardera utfodrades med $20 \mathrm{~kg} 100$ procentigt rodkloverenslage per dag i totalt 14 dagar. Forandring 1 beteende, reproduktionsorgan och hypofysens respons på exogent gondadotropinfrisattande hormon (GnRH) undersoktes. Klıniska effekter som odem och forandring av mucus i vulva, mjolksekretıon samt okning 1 spenstorlek och uterusstorlek observerades under rodkloverensilageutfodring. Ackumulering av vatska i uterus påvisades med ultraljudsteknik. Denna vatskeansamling var bestående aven 30 dagar efter avslutad rodkloverutfodring Rodkloverenslage tycks reducera magnituden och varaktigheten på hypofys-responsen av GnRH.

(Recelved December 6, 1993; accepted March 7, 1994)

Reprints may be requested from: A. Madej, Swedish University of Agricultural Sciences, Faculty of Veterinary Medicine, Department of Physiology, P.O. Box 7045, S-750 07, Uppsala, Sweden. 
